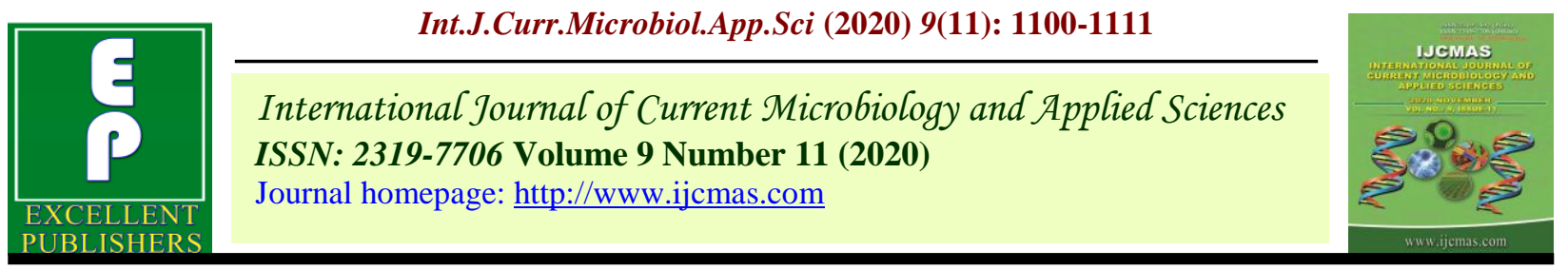

\title{
Response of Defence Related Enzymes in Tomato Treated with Oil-Cakes against Root-knot Nematode, Meloidogyne incognita
}

\author{
B. S. Chandrawat ${ }^{1 *}$, A. U. Siddiqui ${ }^{2}$, S. S. Bhati ${ }^{3}$ and Vinod Saharan ${ }^{4}$ \\ ${ }^{1}$ SKN College of Agriculture, Jobner, SKN Agriculture University, Jobner, India \\ ${ }^{2}$ Department of Nematology, Rajasthan College of Agriculture, Maharana Pratap University \\ of Agriculture and Technology, Udaipur, India \\ ${ }^{3}$ College of Agriculture, Nagur, Agriculture University, Jodhpur, India \\ ${ }^{4}$ Department of MBBT, Rajasthan College of Agriculture, Maharana Pratap University of \\ Agriculture and Technology, Udaipur, India \\ *Corresponding author
}

\section{A B S T R A C T}

Keywords

Tomato, oil-cakes, peroxidase,

Polyphenol oxidase, Phenylalanine ammonia lyase and Superoxide dismutase

Article Info

\section{Accepted:}

10 October 2020

Available Online:

10 November 2020
Plants produce a spacious range of biologically active molecules which have antagonistic properties against plant parasitic nematodes. The peroxidase (PO), polyphenol oxidase (PPO), phenylalanine ammonia lyase (PAL) and superoxide dismutase (SOD) are the most defense enzymes produce by plants during nematode infection. An experiment was conducted to assess the response of defence enzymes PO, PPO, PAL and SOD in tomato roots when treated with oil cakes (castor, mahua, karanj and mustard @ 2.5 and 5.0 q/ha and neem cake @ $5.0 \mathrm{q} / \mathrm{ha}$ as a standard check) against $M$. incognita. The enzymatic activity was assayed in tomato roots and results revealed that application of oil-cakes increased the level of defense enzymes with exposure of time. Among all, the application of mustard cake @ 5.0 q/ha was found best to enhance enzymatic activity from 7 days after inoculation onwards to $28 \mathrm{DAI}$ as compared to untreated check. The lowest enzyme activity in among enzymes was recorded at 60 DAI in untreated control plant roots. Among enzymes the PO was found highest followed by SOD during different time of observations, while PPO and PAL were observed in low quantity. As regard to nematode reproduction, mustard cake @ 5.0 q/ha soil proved best treatment followed by castor and mahua@5.0 q/ha. However, standard check neem cake@5.0 q/ha was found the best treatment to increasing enzymatic activity, improving plant growth characters as well as in reducing nematode population over other treatment.

\section{Introduction}

Root-knot nematode, Meloidogyne incognita infects tomato crop (Alam et al., 1975; Khan et al., 1978) and causing major economic damage to agricultural vegetable production including tomato around the world (Sasser, 1980; Jones et al., 1991; Williamson and Hussey, 1996; Fourie and McDonald, 2000; Anwar et al., 2007).Damage to tomato crop due to nematodes has been documented by various workers. Bhatti and Jain (1977) and 
Sharma and Baheti (1992) estimated the crop losses up to 46 per cent. Reddy (1985) estimated 39.77 per cent loss in tomato field. The tomato yield losses ranging from 32 to $40 \%$ due to root knot nematode has been reported (Anwar and McKenry, 2012). Arya (1957) found its infestation on tomato in Rajasthan.

Plant endo-parasitic nematodes, spend a major part of their life cycles embedded in the roots of a host plant and are therefore exposed to a variety of host defense responses (Jones et al., 2007). Reactive oxygen species (ROS) including superoxide radical $\left(\mathrm{O}_{2}\right)$, hydrogen peroxide $\left(\mathrm{H}_{2} \mathrm{O}_{2}\right)$ and hydroxyl radical $(\mathrm{OH})$ are often detected in plant-pathogen interactions and are associated with symptom development. Plants have acquired the relevant protective defense mechanisms to maintain the lowest possible levels of ROS inside the cell during stress circumstance (Wojtaszek, 1997). However, under stressful conditions, their formation might increase to excess the antioxidant scavenging capacity, thus creating oxidative stress by reaction and damage to all bio-molecules (Halliwell and Gutteridge, 1999). In addition, ROS are highly reactive to membrane lipids, protein and DNA. Reactive oxygen species (ROS) play an important role in plant defence and during pathogen attack, levels of ROS detoxifying enzymes like peroxidase (PO) and catalase (CAT) are often suppressed in resistant plants (Klessing et al., 2000). As a result, plants produce more ROS and accumulation of these components leads to HR in plant cells. For example, hydrogen peroxide plays a major role in triggering $\mathrm{HR}$ in incompatible interactions. Antioxidant enzymes such as PO, PAL, PPO, SOD, POD and CAT are considered to be the main protective enzymes engaged in the removal of free radicals and activated oxygen species (Blokhina et al., 2003; Devi et al., 2000; Chawla et al., 2013). Oxidative enzymes such as $\mathrm{PO}, \mathrm{PAL}, \mathrm{PPO}, \mathrm{SOD}$ and $\mathrm{CAT}$ are reported to be involved in the mechanism of disease resistance. Alterations of plant enzymes mainly peroxidase, poly-phenol oxidase, catalase, superoxide dismutase and protease in the tissues of nematode infected, susceptible and resistant varieties were extensively studied. Such alterations differed in susceptible and resistant cultivars (Molinari, 1995; Sharma, 1993; Zacheo et al., 1987). The root-knot nematode infection increased peroxidase activity, phenol content, polyphenol oxidase activities, phenylalanine ammonia lyase, tyrosin ammonia lyase in roots of cotton, coffee, chick pea, banana and rice (Gregory and Michael, 1978; Mazzafera, 1989; Mishra and Mohanty, 2007; Patel et al., 2001; Sundararaju and Suba, 2006; Xu et al., 2008) In tomato, numerous reports in literature illustrate the influence of the rootknot nematode on roots phenol content, lipid peroxidation, antioxidants and peroxidase activities as defense mechanism against nematode infection (El-Sherif and El-Wakil, 1991; Kuzniak and Sklodowska, 2001). Polyphenol oxidase activity also increased by $16-24 \%$ in resistant cultivars and by $12-18 \%$ in the susceptible one (Hasan and Saxena, 1997). Likewise, peroxidase activity increased in tomato resistant cultivars up to 5 times than that in healthy plants as measured 10 days after inoculation by $M$. incognita and decreased thereafter to normal levels within few days. Also, $M$. incognita resistant varieties of tomato had significantly higher peroxidase (Shukla and Chakraborty, 1988, Zacheo et al., 1993), Polyphenol oxidase (PPO) and indole acetic acid (IAA) (Nagesh et al., 1998) activity than the susceptible varieties. However, few reports illustrate the role of organic matter in improving defense mechanisms of plants against the root-knot nematodes infection.

The present study was carried out to investigate the defense-related enzyme 
responses (PO, PPO, PAL and SOD) of tomato treated with oil-cakes against the rootknot nematode Meloidogyne incognita.

\section{Materials and Methods}

The experiment was laid out in pot filled with root-knot nematode infested soil having 2 juvenile per gram soil obtained from the pure culture plots. Utmost care was taken right from sowing to till harvest of experiment for proper growth and development of plants. The details of material required and methods applied were as follows:

\section{Preparation and maintenance of pure culture of $M$. incognita}

Tomato plants infected with $M$. incognita were uprooted from the pure culture plots of the department and brought to the laboratory. Egg masses, collected from the infected roots and kept in distilled water in cavity block at laboratory temperature for hatching. Freshly hatched $2^{\text {nd }}$ stage juvenile were then inoculated on one month old tomato plants already grown and maintained in 6" sized earthen clay pots filled with steam sterilized soil to obtained adequate pure population of $M$. incognita on the plants and in soil to carry out further experiments.

\section{Disinfection and filling of pots}

$6 "$ size earthen pots were washed, cleaned and disinfected before use by rinsing them with 4 per cent formalin solution. Pots were filled with $1 \mathrm{~kg}$ infested soil. Some space (0.5-1.0") from the above was left unfilled for watering. Castor, mahua, karanj and mustard oil-cakes were added to soil each @ 2.5 and 5.0 $\mathrm{q} /$ hasoil. Each treatment was replicated three times. Untreated and standard check (neem cake @ 5.0 q/ha soil)was also maintained for comparison.

\section{Transplanting and after care}

Uniform size seedlings were transplanted in pots, one healthy plant in each pot was maintained. Care was taken right from sowing till harvest of experiments. To avoid insect damage, spray of Malathion $(0.05 \%)$ was given as and when required. Weeds were uprooted from experimental pots. The pots were randomly rotated to eliminate the effect of sun and shade. The appropriate amount of water was provided throughout the course of experimentation.

\section{Harvest}

Assessment of the response of defence enzymes PO, PPO, PAL and SOD in tomato roots treated with oil-cakes against $M$. incognita was done on every 7days interval after transplanting i.e.7, 14, 21, 28 and 60 days after transplanting. The experiment was harvested 60 days after transplanting, while harvesting, the care was taken to avoid losses of both roots and nematodes in adhering soil. Observation on enzyme analysis and various growth parameters viz., fresh root and shoot weight, shoot and root length were recorded without delay whereas for studying nematode infestation, the plant tissues were stained in $0.1 \%$ acid fuchsin in lacto phenol at $80^{\circ} \mathrm{C}$ for 2-3 minutes (McBeth et al., 1941). Then after gentle wash, roots were kept in clear lacto phenol for $24 \mathrm{hrs}$ and then examined under microscope for nematode infection and observation of number of galls/plant, number of egg masses/plant and number of eggs/egg mass were recorded.

\section{Estimation of soil population}

The soil samples $(200 \mathrm{cc})$ collected from the experimental pots were processed using Cobb's sieving and decanting technique (Cobb, 1918) followed by Baermann's funnel technique (Christie and Perry, 1951). After 24 hrs the suspension was drawn in a beaker 
from the funnel and kept for some time to allow the nematode to settle down. The excess water was gently poured out of the beaker without disturbing the nematodes already settled at bottom.

The volume of suspension was made to 100 $\mathrm{ml}$ and then after thoroughly bubbling $10 \mathrm{ml}$ of suspension was drawn with the help of a pipette and poured over a counting dish for counting. Population count was done under a stereoscopic binocular microscope.

\section{Enzyme analysis}

\section{Determination of peroxidase (po) enzymes in tomato roots}

The method proposed by Hammerschmidt et al., (1982) was adopted for assaying the activity of peroxidase (EC 1.11.1.7). A 20\% homogenate was prepared in $0.1 \mathrm{M}$ phosphate buffer ( $\mathrm{pH}$ 7.0) from the root parts of the plant. The homogenate was centrifuged at $16,000 \mathrm{rpm}$ at $4^{\circ} \mathrm{C}$ for $15 \mathrm{~min}$ and the supernatant was used for the assay. The reaction mixture consisted of $1.5 \mathrm{ml}$ of 0.05 $\mathrm{M}$ pyrogallol, $0.5 \mathrm{ml}$ of enzyme extract and $0.5 \mathrm{ml}$ of 1 per cent $\mathrm{H}_{2} \mathrm{O}_{2}$. The reaction mixture was incubated at room temperature $\left(28 \pm 2{ }^{\circ} \mathrm{C}\right)$. The changes in absorbance at 420 $\mathrm{nm}$ were recorded at $30 \mathrm{~s}$ intervals for $3 \mathrm{~min}$. The enzyme activity was expressed as changes in the absorbance $\mathrm{min}^{-1} \mathrm{mg}^{-1}$ protein

\section{Determination of polyphenol oxidase (ppo) enzymes in tomato roots}

Polyphenol oxidase (EC 1.10.3.1) activity was estimated simultaneously by the method of Mayer et al., (1965). The enzyme extract was prepared by homogenizing $0.5 \mathrm{~g}$ of plant tissue in $2.0 \mathrm{ml}$ of the extraction medium $0.1 \mathrm{M}$ sodium phosphate buffer $(\mathrm{pH} 6.5)$. The homogenate was centrifuged at $16,000 \mathrm{rpm}$ for $15 \mathrm{~min}$ at $4{ }^{\circ} \mathrm{C}$ and the supernatant was used for the assay. The reaction mixture consisted of $200 \mu \mathrm{l}$ of the enzyme extract and $1.5 \mathrm{ml}$ of $0.1 \mathrm{M}$ sodium phosphate buffer $(\mathrm{pH}$ 6.5 ). To start the reaction $200 \mu 1$ of $0.01 \mathrm{M}$ catechol was added and the activity was expressed as changes in absorbance at $495 \mathrm{~nm}$ $\mathrm{min}^{-1} \mathrm{mg}^{-1}$ protein.

Determination of phenylalanine ammonia lyase (pal) enzymes in tomato roots

The activity of phenylalanine ammonia lyase (EC 4.3.1.5) was measured following the method of Dickerson et al., (1984). Root samples $(1 \mathrm{~g})$ were homogenized in $3 \mathrm{ml}$ of ice cold $0.1 \mathrm{M}$ sodium borate buffer, $\mathrm{pH} 7.0$ containing $1.4 \mathrm{mM}$ of 2-mercaptoethanol and $0.1 \mathrm{~g}$ of insoluble polyvinyl pyrrolidine. The extract was filtered through cheese cloth and the filtrate was centrifuged at $16,000 \mathrm{rpm}$ for $15 \mathrm{~min}$.

The supernatant was used as enzyme source. PAL activity was determined as the rate of conversion of L-phenylalanine to transcinnamic acid at $290 \mathrm{nM}$. A sample containing $0.4 \mathrm{ml}$ of enzyme extract was incubated with $0.5 \mathrm{ml}$ of $0.1 \mathrm{M}$ borate buffer, $\mathrm{pH} 8.8$ and $0.5 \mathrm{ml}$ of $12 \mathrm{mM}$ L-phenylalanine in the same buffer for $30 \mathrm{~min}$ at $30^{\circ} \mathrm{C}$. The amount of trans-cinnamic acid synthesized was calculated using its extinction coefficient of $9630 \mathrm{~m}-1$. Enzyme activity was expressed as nmol trans-cinnamic acid $\min ^{-1} \mathrm{mg}^{-1}$ protein.

\section{Determination of super oxide dismutase (sod) enzymes in tomato roots}

SOD was assayed according to the method of Beauchamp and Fridovich (1971). The activity of SOD (EC 1.15.1.1) was assayed by measuring its ability to inhibit the photochemical reduction of NBT. The roots $(0.5 \mathrm{~g})$ were homogenized with $3.0 \mathrm{ml}$ of potassium phosphate buffer, centrifuged at 
$2000 \mathrm{rpm}$ for 10 minutes and the supernatants were used for the assay. The $3 \mathrm{ml}$ reaction mixture contained $50 \mathrm{mM}$ phosphate buffer $\mathrm{pH} 7.8,13 \mathrm{mM}$ methionine, $75 \mu \mathrm{M}$ NBT, 2 $\mu \mathrm{M}$ riboflavin, $1.0 \mathrm{mM}$ EDTA and $20 \mu \mathrm{l}$ enzyme extract. Riboflavin was added last and the reaction was initiated by placing the tubes $30 \mathrm{~cm}$ below $15 \mathrm{~W}$ fluorescent lamps.

The reaction was started by switching on the light and was allowed to run for $10 \mathrm{~min}$. Switching off the light stopped the reaction and the tubes were covered with black cloth. Non-illuminated tubes served as control. The absorbance at $560 \mathrm{~nm}$ was read. One unit of SOD is the amount of extracts that gives $50 \%$ inhibition the rate of NBT reduction.

\section{Results and Discussion}

\section{Plant growth and nematode reproduction}

Data presented in Table 1 and 2 reveal that all tested oil-cakes applied 2.5 and $5.0 \mathrm{q} / \mathrm{ha}$ are remarkably improve plant growth and reduce gall formation, nematode population, number of eggs, egg production capacity as compared to untreated check. Difference in plant growth improvement and nematode reductions were can be seen.

Among all the treatments application of mustard cake@ 5.0 q/ha was found the best treatments to improve plant growth character, reducing number of galls per plant, number of egg masses per plant, number of eggs per egg mass, nematode population/200cc soil and total nematode population of $M$. incognita in tomato.

However, standard check neem cake @ 5.0 $\mathrm{q} / \mathrm{ha}$ was found the best treatment to improving plant growth characters as well as in reducing nematode population over other treatment.

\section{Determination of defence enzymes}

Peroxidase (PO), Polyphenol oxidase (PPO), Phenylalanine ammonia lyase (PAL) and Super oxide dismutase (SOD) were determined in roots of infected tomato plants and those treated with oil-cakes. Results in Table-3 manifested that application of oilcakes increased the level of PO in tomato roots. Among all the treatments application of mustard cake@5.0 q/ha was found to be the best treatments to enhance enzymatic activity. However, standard check Neem cake @ 5.0 $\mathrm{q} / \mathrm{ha}$ was found the best treatment to increase the enzyme activity against $M$. incognita in tomato roots.

The enzyme activity showed gradual increase from 7 DAI onwards to $28 \mathrm{DAI}$ in plant roots treated with oil-cakes as compared to untreated ones. The lowest enzyme activity in among enzymes was recorded at 60 DAI in untreated control plant roots. Among enzymes the PO was found highest in tomato roots during different time of observations followed by SOD, while PPO and PAL were observed in low quantity.

The result presented here shows that application of oil-cakes increase the enzymatic activity in tomato roots, increase plant growth and reduce the nematode population.

This effect of oil-cakes may possibly be attributed to their high contents of certain active compounds which are very effective and target specific to controlling pests of the various crops. Akhtar and Malik (2000), Siddiqui and Alam (2001), they have reported that phenols, amino acids, aldehydes and fatty acids are release from neem which is antagonistic to root knot nematodes. 
Table.1 Effect of oil-cakes on plant growth characters of tomato infected with M. incognita

\begin{tabular}{|c|c|c|c|c|c|c|c|c|c|c|c|c|c|}
\hline \multicolumn{2}{|r|}{ Treatments } & \multicolumn{3}{|c|}{ Shoot length $(\mathrm{cm})$} & \multicolumn{3}{|c|}{ Shoot weight (g) } & \multicolumn{3}{|c|}{ Root length (cm) } & \multicolumn{3}{|c|}{ Root weight (g) } \\
\hline & & $\begin{array}{c}\mathrm{I}^{\text {st }} \\
\text { Year }\end{array}$ & $\begin{array}{l}\mathrm{II}^{\mathrm{st}} \\
\text { Year }\end{array}$ & $\begin{array}{l}\text { Poole } \\
\mathrm{d}\end{array}$ & $\begin{array}{c}\mathrm{I}^{\mathrm{st}} \\
\text { Year }\end{array}$ & $\begin{array}{l}\mathrm{II}^{\mathrm{st}} \\
\text { Year }\end{array}$ & Pooled & $\begin{array}{c}\mathrm{I}^{\mathrm{st}} \\
\text { Year }\end{array}$ & $\begin{array}{l}\mathrm{II}^{\mathrm{st}} \\
\text { Year }\end{array}$ & Pooled & $\mathrm{I}^{\text {st }}$ Year & $\mathrm{II}^{\mathrm{st}}$ Year & Pooled \\
\hline T 1 & $\begin{array}{l}\text { Castor cake @ } \\
2.5 \mathrm{q} / \mathrm{ha} .\end{array}$ & 26.63 & 26.37 & 26.50 & 24.90 & 25.10 & 25.00 & 28.37 & 28.70 & 28.53 & 19.33 & 20.10 & 19.72 \\
\hline T 2 & Castor cake @5q/ha. & 31.87 & 31.20 & 31.53 & 32.23 & 32.08 & 32.16 & 38.80 & 39.13 & 38.97 & 27.20 & 27.38 & 27.29 \\
\hline T 3 & $\begin{array}{l}\text { Mahua cake @ } \\
\text { 2.5q/ha. }\end{array}$ & 25.93 & 25.57 & 25.75 & 23.87 & 23.98 & 23.93 & 27.27 & 27.45 & 27.36 & 18.50 & 19.03 & 18.77 \\
\hline T 4 & Mahua cake@5q/ha. & 30.17 & 30.43 & 30.30 & 30.90 & 31.13 & 31.02 & 37.43 & 37.10 & 37.27 & 26.10 & 25.95 & 26.03 \\
\hline T 5 & $\begin{array}{l}\text { Karanj cake @ } \\
2.5 q / h a .\end{array}$ & 24.40 & 24.73 & 24.57 & 22.00 & 22.17 & 22.08 & 26.83 & 27.10 & 26.97 & 18.33 & 18.50 & 18.42 \\
\hline T 6 & Karanj cake @ 5q/ha. & 28.43 & 28.77 & 28.60 & 29.13 & 28.95 & 29.04 & 35.93 & 36.27 & 36.10 & 24.93 & 24.72 & 24.83 \\
\hline T 7 & $\begin{array}{l}\text { Mustard cake@ } \\
2.5 \mathrm{q} / \mathrm{ha} \text {. }\end{array}$ & 27.40 & 27.63 & 27.52 & 25.97 & 26.30 & 26.13 & 29.83 & 30.17 & 30.00 & 20.67 & 21.42 & 21.04 \\
\hline T 8 & Mustard cake@5q/ha. & 33.10 & 33.43 & 33.27 & 33.97 & 34.17 & 34.07 & 40.67 & 41.00 & 40.83 & 28.90 & 29.23 & 29.07 \\
\hline T 9 & $\begin{array}{l}\text { Neem cake (Standard } \\
\text { check) @ 5q/ha. }\end{array}$ & 34.53 & 34.95 & 34.74 & 35.57 & 35.75 & 35.66 & 42.70 & 43.37 & 43.03 & 30.47 & 30.73 & 30.60 \\
\hline T 10 & Control & 10.80 & 11.13 & 10.97 & 3.63 & 3.77 & 3.70 & 8.97 & 8.60 & 8.78 & 3.20 & 3.10 & 3.15 \\
\hline SEm \pm & & 0.183 & 0.361 & 0.238 & 0.17 & 0.216 & 0.18 & 0.29 & 0.313 & 0.25 & 0.42 & 0.436 & 0.41 \\
\hline CD at & & 0.541 & 1.065 & 0.702 & 0.500 & 0.638 & 0.530 & 0.865 & 0.922 & 0.732 & 1.251 & 1.287 & 1.202 \\
\hline $\mathrm{CV}$ & & 1.163 & 2.280 & 1.505 & 1.12 & 1.42 & 1.18 & 1.60 & 1.70 & 1.35 & 3.37 & 3.43 & 3.22 \\
\hline
\end{tabular}

(1) Data are average value of three replications. (2) Initial inoculums level $2 \mathrm{~J} 2 / \mathrm{g}$ soil 
Table.2 Effect of oil-cakes on $M$. incognita nematode reproduction on tomato plant

\begin{tabular}{|c|c|c|c|c|c|c|c|c|c|c|c|c|c|c|c|}
\hline \multirow[t]{2}{*}{$\begin{array}{l}\text { Treat- } \\
\text { ments }\end{array}$} & \multicolumn{3}{|c|}{ No. of galls/ plant } & \multicolumn{3}{|c|}{ No. of egg masses / plant } & \multicolumn{3}{|c|}{$\begin{array}{c}\text { No. of eggs and larvae / egg } \\
\text { mass }\end{array}$} & \multicolumn{3}{|c|}{$\begin{array}{c}\text { Larval population / 200cc } \\
\text { soil }\end{array}$} & \multicolumn{3}{|c|}{ Total population } \\
\hline & $\begin{array}{l}\mathrm{I}^{\mathrm{st}} \\
\text { Year }\end{array}$ & $\begin{array}{l}\text { II }^{\mathrm{st}} \\
\text { Year }\end{array}$ & $\begin{array}{c}\text { Poole } \\
\text { d }\end{array}$ & $\begin{array}{l}\mathrm{I}^{\mathrm{st}} \\
\text { Year }\end{array}$ & $\begin{array}{l}\text { II }^{\text {st }} \\
\text { Year }\end{array}$ & Pooled & $\mathrm{I}^{\mathrm{st}}$ Year & II $^{\text {st }}$ Year & Pooled & $\begin{array}{c}\mathrm{I}^{\mathrm{st}} \\
\text { Year }\end{array}$ & $\begin{array}{c}\text { II }^{\text {st }} \\
\text { Year }\end{array}$ & Pooled & $\mathrm{I}^{\mathrm{st}}$ Year & II $^{\text {st }}$ Year & Pooled \\
\hline T 1 & 29.33 & 30.00 & 29.67 & 21.33 & 22.33 & 21.83 & 116.00 & 114.00 & 115.00 & 280.00 & 284.00 & 282.00 & 3874.00 & 3964.00 & 3919.00 \\
\hline T 2 & 21.33 & 20.67 & 21.00 & 14.67 & 14.00 & 14.33 & 87.33 & 86.00 & 86.67 & 203.00 & 202.00 & 202.50 & 2296.00 & 2216.00 & 2256.00 \\
\hline T 3 & 30.67 & 30.33 & 30.50 & 23.00 & 23.33 & 23.17 & 128.00 & 130.00 & 129.00 & 303.67 & 305.33 & 304.50 & 4463.00 & 4561.33 & 4512.17 \\
\hline T 4 & 22.67 & 22.00 & 22.33 & 16.00 & 14.67 & 15.33 & 94.33 & 95.67 & 95.00 & 220.00 & 217.00 & 218.50 & 2610.00 & 2489.67 & 2549.83 \\
\hline T 5 & 32.00 & 32.33 & 32.17 & 26.00 & 26.33 & 26.17 & 132.67 & 134.33 & 133.50 & 348.33 & 352.33 & 350.33 & 5190.33 & 5301.33 & 5245.83 \\
\hline T 6 & 23.33 & 22.67 & 23.00 & 18.33 & 17.67 & 18.00 & 99.67 & 98.67 & 99.17 & 232.67 & 229.67 & 231.17 & 2990.33 & 2892.00 & 2941.17 \\
\hline T 7 & 28.33 & 29.00 & 28.67 & 20.33 & 21.33 & 20.83 & 110.00 & 112.00 & 111.00 & 260.00 & 263.00 & 261.50 & 3537.33 & 3704.33 & 3620.83 \\
\hline T 8 & 19.67 & 20.00 & 19.83 & 13.67 & 13.33 & 13.50 & 80.00 & 79.33 & 79.67 & 191.00 & 192.67 & 191.83 & 2049.67 & 2022.00 & 2035.83 \\
\hline T 9 & 18.33 & 17.67 & 18.00 & 11.67 & 11.00 & 11.33 & 74.33 & 75.67 & 75.00 & 179.33 & 174.00 & 176.67 & 1764.33 & 1703.33 & 1733.83 \\
\hline T 10 & 65.00 & 66.67 & 65.83 & 52.00 & 53.67 & 52.83 & 211.00 & 215.00 & 213.00 & 908.33 & 920.00 & 914.17 & 15511.00 & 16130.33 & 15820.67 \\
\hline SEm \pm & 0.69 & 0.61 & 0.60 & 0.68 & 0.81 & 0.69 & 1.61 & 1.45 & 1.35 & 5.01 & 3.23 & 3.88 & 133.18 & 124.08 & 124.68 \\
\hline $\begin{array}{l}\mathrm{CD} \text { at } \\
5 \%\end{array}$ & 2.05 & 1.79 & 1.76 & 2.00 & 2.39 & 2.05 & 4.75 & 4.28 & 4.00 & 14.77 & 9.51 & 11.45 & 392.89 & 366.03 & 367.81 \\
\hline CV & 4.13 & 3.61 & 3.56 & 5.41 & 6.45 & 5.54 & 2.46 & 2.20 & 2.06 & 2.77 & 1.78 & 2.15 & 5.21 & 4.78 & 4.84 \\
\hline
\end{tabular}

(1) Data are average value of three replications. (2) Initial inoculums level $2 \mathrm{~J} 2 / \mathrm{g}$ soil. 
Table.3 Effect of oil-cakes on peroxidase (PO), poly phenol oxidase (PPO), phenylalanine ammonia lyase (PAL) and super oxide dismutase (SOD) activity in tomato roots infected with $M$. incognita

\begin{tabular}{|c|c|c|c|c|c|c|c|c|c|c|c|c|c|c|c|c|c|c|c|c|}
\hline \multicolumn{21}{|c|}{ Specific activity of Enzymes (umol/min/gm) } \\
\hline DAI & 7 & 14 & 21 & 28 & 60 & 7 & 14 & 21 & 28 & 60 & 7 & 14 & 21 & 28 & 60 & 7 & 14 & 21 & 28 & 60 \\
\hline Treat-ments & \multicolumn{5}{|c|}{ PO } & \multicolumn{5}{|c|}{ PPO } & \multicolumn{5}{|c|}{ PAL } & \multicolumn{5}{|c|}{ SOD } \\
\hline T 1 & 14.520 & 25.375 & 34.877 & 41.842 & 8.092 & 0.207 & 0.363 & 0.516 & 0.598 & 0.160 & 0.115 & 0.180 & 0.255 & 0.303 & 0.101 & 1.76 & 2.77 & 2.99 & 3.36 & 0.98 \\
\hline T 2 & 31.494 & 40.827 & 47.171 & 58.280 & 18.919 & 0.273 & 0.418 & 0.559 & 0.710 & 0.229 & 0.144 & 0.194 & 0.290 & 0.342 & 0.117 & 2.10 & 3.34 & 3.63 & 3.77 & 1.13 \\
\hline T 3 & 12.800 & 21.823 & 33.750 & 39.614 & 7.302 & 0.196 & 0.359 & 0.505 & 0.576 & 0.149 & 0.112 & 0.178 & 0.241 & 0.299 & 0.098 & 1.74 & 2.56 & 2.86 & 3.25 & 0.90 \\
\hline T 4 & 30.704 & 39.840 & 45.986 & 56.137 & 17.171 & 0.265 & 0.411 & 0.552 & 0.704 & 0.221 & 0.141 & 0.192 & 0.279 & 0.331 & 0.115 & 2.01 & 3.23 & 3.52 & 3.73 & 1.09 \\
\hline T 5 & 11.024 & 20.582 & 33.524 & 38.402 & 6.541 & 0.186 & 0.354 & 0.497 & 0.567 & 0.144 & 0.109 & 0.174 & 0.234 & 0.292 & 0.097 & 1.66 & 2.43 & 2.70 & 3.19 & 0.86 \\
\hline T 6 & 28.562 & 38.092 & 32.480 & 54.501 & 15.479 & 0.255 & 0.407 & 0.548 & 0.700 & 0.217 & 0.138 & 0.189 & 0.285 & 0.326 & 0.114 & 1.97 & 3.12 & 3.41 & 3.69 & 1.02 \\
\hline T 7 & 15.366 & 25.968 & 39.163 & 42.885 & 9.078 & 0.215 & 0.369 & 0.524 & 0.623 & 0.168 & 0.118 & 0.183 & 0.263 & 0.314 & 0.102 & 1.80 & 2.86 & 3.09 & 3.48 & 0.99 \\
\hline T 8 & 33.862 & 42.885 & 47.960 & 59.407 & 20.751 & 0.281 & 0.421 & 0.571 & 0.718 & 0.237 & 0.146 & 0.196 & 0.295 & 0.348 & 0.118 & 2.14 & 3.40 & 3.73 & 3.86 & 1.15 \\
\hline T 9 & 36.084 & 50.272 & 71.334 & 73.167 & 29.971 & 0.299 & 0.464 & 0.611 & 0.765 & 0.275 & 0.156 & 0.211 & 0.302 & 0.366 & 0.130 & 2.18 & 3.49 & 3.96 & 3.99 & 1.24 \\
\hline T 10 & 4.511 & 9.530 & 17.340 & 23.515 & 3.834 & 0.109 & 0.169 & 0.180 & 0.130 & 0.080 & 0.072 & 0.084 & 0.094 & 0.076 & 0.045 & 1.115 & 1.29 & 1.605 & 1.79 & 0.21 \\
\hline $\mathrm{SEm}_{ \pm}$ & 0.022 & 0.016 & 0.015 & 0.003 & 0.003 & 0.002 & 0.002 & 0.001 & 0.002 & 0.001 & 0.026 & 0.038 & 0.055 & 0.069 & 0.021 & 0.404 & 0.625 & 0.705 & 0.744 & 0.212 \\
\hline CD at $5 \%$ & 0.065 & 0.047 & 0.044 & 0.009 & 0.010 & 0.006 & 0.005 & 0.002 & 0.005 & 0.002 & 0.077 & 0.113 & 0.162 & 0.203 & 0.062 & 1.191 & 1.845 & 2.079 & 2.194 & 0.625 \\
\hline $\mathrm{CV}$ & 0.17 & 0.09 & 0.06 & 0.01 & 0.04 & 1.43 & 0.80 & 0.20 & 0.53 & 0.60 & 4.61 & 3.59 & 2.69 & 1.92 & 5.65 & 0.35 & 0.20 & 0.19 & 0.17 & 0.35 \\
\hline
\end{tabular}

(1)Data are average value of three replications. (2) Initial inoculums level $2 \mathrm{~J} 2 / \mathrm{g}$ soil 
Similarly, some researchers have reported that use of organic amendments, composts, neem, poultry, inorganic fertilizers and nematicide (nemacur $10 \mathrm{G}$ )] reduced number of galls, nematode reproduction, fecundity increased Plant chemicals (MDA contents, $\mathrm{H}_{2} \mathrm{O}_{2}$, glutathione, Ascorbic acid, Soluble protein) and increased antioxidant substances (SOD, APOX, CAT, PAL, Glutathione-Stransferase) over control in tomato (Hossam et al., 2012) fruit extract of neem induces defense response through enhanced activities of phenylalanine ammonia-lyase, tyrosine ammonia-lyase, polyphenol oxidase, peroxidase in tomato (Bhuvaneshwari and Paul, 2012). Goel and Paul (2014) evaluated that neem extract significantly reduced disease severity in the treated plants by inducing activities of $\mathrm{PO}$ and Lipoxygenase. Xiao, Z. (2016) found vermin-compost could significantly suppress root pests via modulating soil properties as well as plant defences, particularly for the susceptible plant. Findings of parihar et al., (2015) is that use of Pochonia chlamydosporia, oil cakes of neem, mustard and cotton were effectively suppressed the nematode population and kept the infection at significantly low levels. These are capable of producing secondary metabolites, which have an allelopathic effect and induces plant resistance against the invasion of nematodes.Findings of Resha and Savita Rani (2015) shows the application of various parts of neem (seeds, leaves) altered the physiology of host plant and developed the strong defensive mechanism of the root against nematodes, it increases plant growth and juvenile's mortality, reduction in egg hatching and root knot formation.

In present study thus it may be concluded that changes in defence enzymes after infection are related to defence action of plant, because abnormal metabolites are produced in contiguous un-infected tissues. Such metabolites collected in infected tissues and are harmful to parasites and suppress their growth and penetration. The metabolites released from the chemical constituents of oilcakes stirred the plant cells to release abnormal metabolites which revolt the nematodes from the un-infected plant cells. So, the use of neem, castor, mahua, karanj and mustard oil-cakes stimulated and changes the physiology of plant cells and tissue to induce the defence enzymes, revolt the nematode parasites.

\section{Acknowledgements}

Author is thankful to Department of Nematology and Department of Molecular Biology and Biotechnology, Rajasthan College of Agriculture, MPUAT, Udaipur for providing facilities and necessary requirement for experimentation.

\section{References}

Akhtar, M. and Malik, A. 2000. Roles of organic amendments and soil organisms in the biological control of plant parasitic nematode: A Review. Bioresource Technology. 74: 35-47.

Alam, M.M., Hasan, N. and Saxena, S.K. 1975. Influence of concomitant population on Meloidogyne incognita and Tylenchorhynchus brasssicae on their development and on the growth on tomato. Indian Journal of Nematology, 5, 247-249.

Anwar, S.A. and Mckenry, M.V. 2012. Incidence and population density of plant-parasitic nematodes infecting vegetable crops and associated yield losses. Pakistan Journal Zoology, 44, 327-333.

Anwar, S.A., Zia, A., Hussain, M. and Kamran, M. 2007. Host suitability of selected plants to Meloidogyne incognita in the Punjab, Pakistan. Journal of Nemtology, 17, 144-150. 
Arya, H.C. (1957). Root-knot diseases of tomatoes in Jodhpur. Science and Culture, 22, 391-393.

Beauchamp, C. and Fridovich, I. 1971. Superoxide dismutase: improved assays and assay applicable to acrylamide gels. Anal Biochemistry, 44, 276-287.

Bhatti, D.S. and Jain, R.K. 1977. Estimation of losses in okra, tomato and brinjal yield due to Meloidogyne incognita. Indian Journal of Nematology7, 3741.

Bhuvaneshwari, V. and Paul, P.K. 2012. Transcriptional and translational regulation of defense enzymes induced by neem fruit extract in tomato. Archives of Phytopathology and Plant Protection, 45, 1-12.

Blokhina, O., Virolainen, E. and Eagersledt, K.V. 2003. Antioxidants, oxidative damage and oxygen deprivation stress: A review. Annals of Botany, 91, 179194.

Chawla, N., Choudhary, K., Kaur, S. and Jindal, S. 2013. Changes in antioxidative enzymes in resistant and susceptible genotypes of tomato infected with root-knot nematode (Meloidogyne incognita). Indian Journal of Nematology, 43, 1-12.

Christie, J.R. and Perry, V.G. 1951. Removing nematode from soil. Proceedings of Heminthological Society of Washington18, 106-108.

Cobb, N.A. 1918. Estimating the nematode population of soil U. S. Dept. Agr. Bur. Plant. Ind. Agr. Tech. Cir.1, 148.

Devi, G.S., Prasad, M.H., Saraswati, I., Raghu, D. and Rao, D.N. 2000. Free radicals antioxidant enzymes and lipid peroxidation in different types of leukemias. Clin Chin Acta, 293, 5362.

Dickerson, D.P., Pascholati, S., Hagerman,
A.E., Butler, L.G. and Nicholson, R.L. 1984. Phenylalanine ammonia lyase and hydroxycinnamate: CoA ligase in maize mesocotyls inoculated with Helminthosporium maydisor and $H$. carbonzlm. Physiological Plant Pathology, 25, 111- 123.

El-Sherif, A.G. andElwakil, M.A. 1991. Interaction between Meloidogyne incognita and Agrobacterium tumefaciens or Fusarium oxysporum f.sp. lycopersici on tomato. Journal of Nematology, 23, 239-242.

Fourie, H. and McDonald, A.H., 2000. Nematodes. ARCLNR Leaflet. Crop Prot. Ser.18, 4-8.

Goel, N. and Paul, P.K. 2014. Neem fruit extract induces peroxidase and lipoxygenase in tomato. Asian Journal of Biological and Life Sciences, 3, 189-194.

Gregory, R.N. and Michael, A.M. 1978. Peroxidase and6-phosphogluconate Dehydrogenase in resistant and susceptible cotton infected by Meloidogyne incognita. Journal of Nematology, 10, 34-39.

Halliwell, B. and Gutteridge, J.M.C. 1999. Free radicals in biolog y and medicine, 3rd Ed. Oxford University Press Oxford.

Hammerschmidt, R., Nuckles, E.M. and Kuc, J. 1982. Association of enhanced peroxidase activity with induced systemic resistance of cucumber to Colletotrichum lagenarium. Physiological Plant Pathology, 20, 73-82.

Hasan, N. and Saxena, S.K. 1997. Effect of inoculating tomato with root-knot nematode, Meloidogyne incognita on phenolic content and polyphenol oxidase activity, Physiological Host Pathogen Interaction. Current Trends Life Sciences, 6, 199-203.

Hossam, S.E., Farahat, A.A., Alsayed, A.A. 
and Mahfoud, N.A. 2012. Response of antioxidant substances and enzymes activities as a defense mechanism against root-knot nematode infection. Notulae Botanicae Horti Agro botanici Cluj-Napoca40, 132-142.

Jones, J.B., Jones, J.P., Stall, R.E. and Zitter, T.A. 1991. Compendium of Tomato Diseases. An. Phytopathol. Soc., St. Paul, MN.

Khan, A.M., Saxena, S.K. and Kheir, M.W. 1978. Interaction of Rhizoctonia solani (Kuhn) and Tylenchorhynchus brassicae (Siddiqi, 1961) in preemergence damping off of cauliflower seedling. Indian Journal of Nematology1, 85-86.

Klessing, D.F., Dumer, J. and Noad, R. 2000. Nitric oxide and salicylic acid signaling in plant defense. Proceedings of Nature Academic Sciences USA 97,8849-8855.

Kuzniak, E. and Skłodowska, M. 2001. Ascorbate, glutathione and related enzymes in chloroplasts of tomato leaves infected by Botrytis cinera. Plant Science, 160(4), 723-731.

Mayer, A.M., Harel, E. and Shaul, R.B. 1965. Assay of catechol oxidase a critical comparison of methods. Phytochemistry, 5, 783-789.

Mazzafera, P., Goncalves, W., Fernandes, J.A.R. 1989. Phenols, peroxidase and polyphenol oxidase in the resistance of coffee to Meloidogyne incognita. Bragantia 48(2), 131-142.

McBeth, C.W., Taylor, A.L. and Smith, A.L. 1941. Note on staining nematodes in root tissues. Proceeding of Helminthological Society of Washington8, 26.

Mishra, C.D. and Mohanty, K.C. 2007. Role of phenolics and enzymes in imparting resistance to rice plants against rootknot nematode, Meloidogyne graminicola. Journal of Nematology
37(2), 131-134.

Molinari, S. 1995. Difference in isoperoxidase activities of tomato roots susceptible and resistant to rootknot nematodes. Nematologia Mediterranea 23(2), 271-281.

Nagesh, V., Welch, K.M., Windham, J.P., Patel, S., Levine, S.R., Hearshen, D., Peck, D., Robbins, K., D’Olhaberriague, L., Soltanian, Z.H. and Boska, M.D. 1998. Time course of $\mathrm{ADCw}$ changes in ischemic stroke: beyond the human eye.Stroke 29, 1778-1782.

Parihar, K, Rehman, B, Ganai, M.A., Asif, M. andSiddiqui, Mansoor A. 2015. Role of oil cakes and Pochonia chlamydosporia for the management of Meloidogyne javanica attacking Solanum melongena L. J Plant Pathol Microbiol. S1: 004. doi:10.4172/21577471.S1-004

Patel, B.A., Patel, D.J., Patel, R.G.andTalati, J.G. 2001. Biochemical changes induced by infection of Meloidogyne spp. in chickpea. ICPN 8, 13-14.

Reddy, D.D.R. 1985. Analysis of crop losses in tomato due to Meloidogyne incognita. Indian Journal of Nematology, 7, 31-41.

Resha and Savita Rani2015. Management of root knot nematode Meloidogyne incognita using neem (Azadiracta indica). Journal of Environmental Science, Toxicology and Food Technology. 9 (3 III), 12-15.

Sasser, J.N. 1980. Root-knot nematode: Aglobal menace to Crop Production. Plant Disease, 64(1), 36-41.

Sharma, G.L. and Baheti, B.L. 1992. Loss estimates due to root-knot nematode in pea, okra, tomato and bottle-gourd crops in Rajasthan, India. Current Nematology, 3, 187-188.

Sharma, O.N. 1993. Enhancement of biological defense mechanisms in 
resistance and its activation in susceptible tomato cultivars infested with root-knot nematode, Meloidogyne incognita. Plant Disease Research 8, 47-53.

Shukla, Y.M. and Chakraborty, M.K. 1988. Biochemical studies on response of tobacco and tomato plants to root-knot nematode infection. Tobacco Research, 14(1), 43-50.

Siddiqui, M. A. and Alam, M.M. 2001. IPM of Ecofriendly Agriculture. 23: 9-11.

Sundararaju, P. and Suba, K.P. 2006. Biochemical changes in banana plants induced by Pratylenchus coffeae and Meloidogyne incognita. Indian Journal of Nematology, 36(2), 256259.

Williamson, V.M. and Hussey, R.S., 1996. Nematode pathogenesis and resistance in plants. Plant Cell8, 1735-1745.

Wojtaszek, P. 1997. Oxidative burst: an early plant response to pathogen infection. Biochemical Journal 322, 681-692.

Xiao, Z., Liu, M., Jiang, L., Chen, X.,
Griffiths, B.S., Li, H. and Hu, F. 2016. Vermi-compost increases defense against root-knot nematode (Meloidogyne incognita) in tomato plants. Applied Soil Ecology105, 177186

Xu, X.M., Xu, K., Yu, Q. and Zhang, X. 2008. The relationship between resistance to Meloidogyne incognita and phenylpropanes metabolism in roots of eggplant root-stock. Acta Phytophylacica Sinica 35(1), 43-46.

Zacheo, G., Bleve, Z.T., Pricolo, G. and Zacheo, T.B. 1987. Metabolic changes in enzyme levels in potato roots infested by potato-cyst nematode, Globodera pallida (Pa3) and Globodera rostochiensis (R01). Nematologia Mediterranea 15(2), 293-302.

Zacheo, G., Orlando, C., andBelve, Z.T. 1993. Characterization of anionic peroxidases in tomato isolines infected by Meloidogyne incognita. Journal of Nematology 25(2), 249-259.

\section{How to cite this article:}

Chandrawat, B. S., A. U. Siddiqui, S. S. Bhati and Vinod Saharan. 2020. Response of Defence Related Enzymes in Tomato Treated with Oil-Cakes against Root-knot Nematode, Meloidogyne incognita. Int.J.Curr.Microbiol.App.Sci. 9(11): 1100-1111. doi: https://doi.org/10.20546/ijcmas.2020.911.127 